\title{
Manipulation of pH Shift to Enhance the Growth and Antibiotic Activity of Xenorhabdus nematophila
}

\author{
Yonghong Wang, ${ }^{1}$ Xiangling Fang, ${ }^{2}$ Yongpeng Cheng, ${ }^{1}$ and Xing Zhang1 \\ ${ }^{1}$ Research and Development Center of Biorational Pesticides, College of Plant Protection, Northwest A \& F University, Yangling, \\ Shaanxi 712100, China \\ ${ }^{2}$ School of Plant Biology, The University of Western Australia, 35 Stirling Highway, Crawley, WA 6009, Australia
}

Correspondence should be addressed to Xing Zhang, ylagri@126.com

Received 2 September 2010; Accepted 19 March 2011

Academic Editor: Ali Khraibi

Copyright (C) 2011 Yonghong Wang et al. This is an open access article distributed under the Creative Commons Attribution License, which permits unrestricted use, distribution, and reproduction in any medium, provided the original work is properly cited.

To evaluate the effects of $\mathrm{pH}$ control strategy on cell growth and the production of antibiotic (cyclo(2-Me-BABA-Gly)) by Xenorhabdus nematophila and enhance the antibiotic activity. The effects of uncontrolled- (different initial $\mathrm{pH}$ ) and controlled-pH (different constant $\mathrm{pH}$ and $\mathrm{pH}$-shift) operations on cell growth and antibiotic activity of $X$. nematophila YL00I were examined. Experiments showed that the optimal initial $\mathrm{pH}$ for cell growth and antibiotic production of $X$. nematophila YL001 occurred at 7.0. Under different constant $\mathrm{pH}$, a $\mathrm{pH}$ level of 7.5 was found to be optimal for biomass and antibiotic activity at $23.71 \mathrm{~g} / \mathrm{L}$ and 100.0 U/mL, respectively. Based on the kinetic information relating to the different constant $\mathrm{pH}$ effects on the fermentation of $X$. nematophila YL001, a two-stage $\mathrm{pH}$ control strategy in which $\mathrm{pH} 6.5$ was maintained for the first $24 \mathrm{~h}$, and then switched to 7.5 after $24 \mathrm{~h}$, was established to improve biomass production and antibiotic activity. By applying this $\mathrm{pH}$-shift strategy, the maximal antibiotic activity and productivity were significantly improved and reaching $185.0 \mathrm{U} / \mathrm{mL}$ and $4.41 \mathrm{U} / \mathrm{mL} / \mathrm{h}$, respectively, compared to values obtained from constant $\mathrm{pH}$ operation $(100.0 \mathrm{U} / \mathrm{mL}$ and $1.39 \mathrm{U} / \mathrm{mL} / \mathrm{h})$.

\section{Introduction}

$X$. nematophila is a Gram-negative bacterium, belonging to the family Enterobacteriaceae which is symbiotically associated with the entomopathogenic nematode in the genus Steinernema (Steinernematidae) [1]. The production of metabolites with antibiotic properties is a characteristic common to the bacteria. $X$. nematophila has been known to produce xenocoumacins (benzopyranone derivatives) [2], nematophin (indoles derivatives) [3], benzylineacetone (monoterpenoid) [4], and xenematide (peptides) [5]. These metabolites not only have diverse chemical structures, but also have a wide range of bioactivities of medicinal and agricultural interest, such as antibiotic, antimycotic, insecticidal, nematicidal, antiulcer, antineoplastic, and antiviral properties [6]. Xenocoumacins are highly active against Grampositive bacteria and also exhibit antimycotic activity against species of Cryptococcus, Aspergillus, Trichophyton, and Candida [2]. Nematophin is also active against Gram-positive bacteria and a plant-pathogenic fungus, Botrytis cinerea.
In comparison, benzylineacetone and xenematide are active against Gram-negative bacteria. These naturally occurring antibiotics provide useful leads in the research and development of drugs and agrochemicals.

We isolated a new strain of X. nematophila YL001 from the symbiotic nematode, Steinernema sp. YL001, collected in China, and the strain has unique genetic (e.g., 16S ribosomal DNA sequence) and biochemical characteristics compared to other isolates of this taxon $[7,8]$. In vitro and In vivo, the bacterium showed high antibiotic activity against some bacteria and fungi such as Phytophthora capsici, Blumeria graminis and Pseudoperonospora cubensis, which have not been thoroughly evaluated as antifungal targets of $X$. nematophila [9]. The study showed for the first time the potential of these products to control diseases of living plants although such crude mixtures were unlikely to be registered for use in commercial agriculture. Moreover, a new antibiotic, cyclo(2-Me-BABA-Gly), was isolated from the strain [10]. The results suggest that X. nematophila YL001 is 
a unique, potential resource of new agrochemicals and antimicrobial compounds.

Antibiotic types and concentration produced by $X$. nematophila depend on the strains of bacteria and their culture conditions [6]. In general, for metabolite biosynthesis, the optimal conditions used for cell growth and metabolites biosynthesis may be quite different. The cell growth and product accumulation vary with medium composition and process parameters, including $\mathrm{pH}$. In order to obtain high biomass and metabolites, it is important to optimize the conditions for cell growth and metabolite biosynthesis during $X$. nematophila fermentation. Well-directed process parameters shift representing a valuable control strategy will be beneficial to the cell growth and metabolite biosynthesis. $\mathrm{pH}$-shift operation has been proven to be an effectual strategy for the production of bioactive metabolites in other microorganism [11-16].

In previous studies, it was found that initial $\mathrm{pH}$ played an important role in the antibiotic production by $X$. nematophila [17-19]. However, until now, there is no report about the effect of $\mathrm{pH}$ control strategy on cell growth and antibiotic activity of this bacterium. Therefore, it would be interesting to investigate whether the $\mathrm{pH}$ control strategy will lead to a quantum improvement in its biomass and antibiotic activity. The objective of this work was to evaluate the effects of $\mathrm{pH}$ control strategy on cell growth and antibiotic activity in batch fermentation by $X$. nematophila YL001. An optimum pH control strategy was proposed to optimize its cell growth and metabolites biosynthesis, and the fermentation efficiency was greatly improved. This work is expected to help develop the large-scale fermentation of $X$. nematophila for the simultaneous production of biomass and antibiotics. The outcome of this work is expected to help in the development of other strains for useful metabolite production.

\section{Materials and Methods}

2.1. Microorganism. X. nematophila YL001 was isolated from its nematode symbiont, Steinernema sp. YL001 was obtained from the soil of Yangling, China. Phase I variant of the bacteria was used throughout the study.

$X$. nematophila YL001 was maintained on nutrient agar (NA) slants and subcultured monthly. NBTA medium, NA supplemented with triphenyltetrazolium chloride $0.040 \mathrm{~g} / \mathrm{L}$ and bromothymol blue $0.025 \mathrm{~g} / \mathrm{L}$, was used to test the phase variant of the bacteria. Phase I is distinguished from phase II by its adsorption of bromothymol blue to produce a red core colony overlaid by dark blue and surrounded by a clear zone after 2-3 days of incubation in darkness at $28^{\circ} \mathrm{C}$.

2.2. Inoculum Preparation. A loopful of the phase I of $X$. nematophila YL001 growing on an NBTA plate was inoculated into a $250 \mathrm{~mL}$ flask containing $100 \mathrm{~mL}$ fresh NB (NA without agar) medium, which was adjusted to a final $\mathrm{pH}$ of 7.20 and then cultured in darkness at $28^{\circ} \mathrm{C}$ on an Eberbach rotary shaker at $150 \mathrm{rpm}$ for $16-24 \mathrm{~h}$, during which time the optical density $(600 \mathrm{~nm})$ was approximately between 1.50 and 2.00 .

2.3. Fermentation Process in Shake Flask. The effect of initial $\mathrm{pH}$ on cell growth and antibiotic activity of the strain was studied using shake flask cultures at different initial $\mathrm{pH}$ values. $250 \mathrm{~mL}$ Erlenmeyer flask contained $50 \mathrm{~mL}$ medium consisting of the following components $(\mathrm{g} / \mathrm{L})$ : glucose 6.13, peptone 21.29, $\mathrm{MgSO}_{4} \cdot 7 \mathrm{H}_{2} \mathrm{O}$ 1.50, $\left(\mathrm{NH}_{4}\right)_{2} \mathrm{SO}_{4} 2.46$, $\mathrm{KH}_{2} \mathrm{PO}_{4} 0.86, \mathrm{~K}_{2} \mathrm{HPO}_{4} 1.11$, and $\mathrm{Na}_{2} \mathrm{SO}_{4}$ 1.72. The medium $\mathrm{pH}$ was adjusted to $4.5,6.5,7.5$, and 9.5 by adding $1 \mathrm{~mol} / \mathrm{L}$ $\mathrm{NaOH}$ or $1 \mathrm{~mol} / \mathrm{L} \mathrm{HCl}$. Ten percent (v/v) of the seed culture was used to inoculate the flasks. The culture was incubated on a rotary shaker at $28^{\circ} \mathrm{C}$ and $150 \mathrm{rpm}$ for $72 \mathrm{~h}$. Three batches were repeated for each experiment.

2.4. Batch Fermentation Process in 5-L Laboratory-Scale Fermenter. The effect of $\mathrm{pH}$ on the strain culture was also studied by batch fermentation in a 5-L bioreactor (Eastbio, China) with a working volume of $3.5 \mathrm{~L}$. The fermenter was equipped with one six-blade disk turbine impeller, the probes of $\mathrm{pH}$ (Mettler-Toledo $\mathrm{GmbH}$, Switzerland), DO (Mettler-Toledo GmbH, Switzerland), temperature, and foam. Temperature, $\mathrm{pH}$, dissolved oxygen, and agitation speed were measured online. The medium, inoculum ratio and temperature used in this study were the same as that of the shake flask culture. The other main operation conditions were aeration ratio of $2.5 \mathrm{~L} / \mathrm{min}$ and agitation speed of $300 \mathrm{rpm}$. A pH profile was adjusted to a set $\mathrm{pH}$ with $2.0 \mathrm{~mol} / \mathrm{L} \mathrm{NaOH}$ and $2.0 \mathrm{~mol} / \mathrm{L} \mathrm{HCl}$. Temperature levels were maintained automatically. The fermenters were incubated according to the culture condition for $72 \mathrm{~h}$. Four cultures were carried out simultaneously in the fermenter with homogeneous cell source under well-controlled process conditions but at different test culture conditions.

2.4.1. Different Constant $p H$ Culture. The significance of different constant $\mathrm{pH}$ on $X$. nematophila YL001 growth and metabolites accumulation was studied by setting culture $\mathrm{pH}$ at $4.5,6.5,7.5$, and 9.5 during the entire fermentation process in the fermenter. For comparison, the control experiment was initially run at a $\mathrm{pH}$ of 7.0, with no farther to adjustment to $\mathrm{pH}$ (i.e., at an initial $\mathrm{pH}$ of 7.0).

2.4.2. pH-Shift Culture. Based on the impact of culture $\mathrm{pH}$, a $\mathrm{pH}$-shift culture was proposed by combining the first stage at a $\mathrm{pH}$ of 6.5 with the following culture at $\mathrm{pH} 7.5$ (i.e., the second stage). The control experiment was conducted without the $\mathrm{pH}$ control in the second-stage culture for comparison. The impact of shift time between the cell growth phase and antibiotic accumulation phase was investigated by setting the shift time on $12,24,36$, and $48 \mathrm{~h}$. The other culture conditions were the same as in the experiments above.

\subsection{Analytical Methods}

2.5.1. Assay of Antibiotic Activity. The antibiotics were extracted as $\mathrm{Li}[10]$. X. nematophila YL001 were cultured 
as described above. Samples of ca. $30 \mathrm{~mL}$ were withdrawn each $6 \mathrm{~h}$ approximately. An amount of $20 \mathrm{~mL}$ aliquots of the fermentation broth were centrifuged (RCF $22400 \times \mathrm{g}$, $20 \mathrm{~min}, 4^{\circ} \mathrm{C}$, Himac $\mathrm{CR} 22 \mathrm{G}$ ) to separate the bacterial

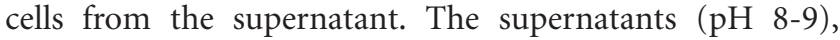
containing the proteinaceous component, were subjected to ammonium sulphate precipitation to remove the protein by filtration. The filtrate was then placed on the top of a column which had been filled with activated D101 macroporous adsorption resin (Shanghai Hualing Resin Co., Ltd, China). After washing the column with distilled water, the column was eluted with methanol. The extract was lyophylized and then redissolved in $\mathrm{H}_{2} \mathrm{O}(20 \mathrm{~mL})$ and bioassayed by agar diffusion plate assay with Bacillus subtilis [20]. Briefly, $1 \mathrm{~mL}$ of the subculture containing $10^{7}-10^{8}$ cells of $B$. subtilis was applied to NA plate. After $2 \mathrm{~h}$ incubation at $28^{\circ} \mathrm{C}, 6-\mathrm{mm}$ disc filters (Whatman 3-mm paper; Whatman, Clifton, NJ) treated with the extracts $(50 \mu \mathrm{L})$ were put on the NA plate and incubated at $28^{\circ} \mathrm{C}$ for $48 \mathrm{~h}$ to determine the relationship between the size of the zones of inhibited bacterial growth and the concentration of the antibiotic. Zones of inhibition were measured from the edge of antibiotic disk to the margin of the zone of inhibition. Antibiotic activity was expressed as units of activity per milliliter (supernatants) of the cultures, where $1 \mathrm{U}$ was defined as a $1.0 \mathrm{~mm}$ annular clearing around the antibiotic disk.

To confirm the assumption that changes in the size of the zones of inhibition (expressed as units of activity per milliliter the supernatants of culture) represented changes in antibiotic concentrations, the extracted antibiotics were diluted with water or concentrated by lyophilization and resuspension in fixed volumes of distilled water. The antibiotic levels, based upon dilution or concentration of the antibiotic extract, ranged from $1 / 10$ to twice the concentration found in the culture. The relationship of the $\log _{10^{-}}$ transformed concentration of the antibiotic relative to the level in the unmodified extract $(20 \mathrm{~mL}$ ) (which was assigned a valueof 1.00) (antibiotic levels of $0.1,0.5,1.0,1.5$, and 2.0 [ $\log$ transformations of $-1,-0.3,0.00,0.18$ and 0.30 , resp.]) to the diameter of the zone of inhibition $(9.5,13.5$, 16.7, 19.3, and $21.5 \mathrm{~mm})$ revealed a linear correlation $(r=$ $0.972 ; P>.05)$. Similarly, $\log _{10}$-transformed concentrations of the antibiotic (cyclo(2-Me-BABA-Gly)) (antibiotic concentrations of $5.0,10.0,15.0,20.0$, and $25.0 \mu \mathrm{g} / \mathrm{mL}$ [logtransformed concentrations of $0.699,1.00,1.177,1.301$ and 1.398 , resp.]) produced inhibition zones $(23.0,25.0,27.0$, 29.0 , and $29.5 \mathrm{~mm})$ that were linearly correlated $(r=$ 0.987; $P>.05)$. Thus, both procedures validated the use of the size of the zone of inhibition as an indicator of antibiotic concentration. Maxwell et al. [20] confirmed the assumption that the changes in the size of the zones of inhibition (expressed as units of activity per gram of insect tissue) represented changes in antibiotic concentration. The antibiotics were extracted from insect larvae killed by $X$. nematophila by homogenizing the insects in distilled water. The assumption has been used successfully to measure the antibiotic activity of X. nematophila YL001 [19, 21]. Therefore, the size of the zones of inhibition served as a measure of antibiotic titer of X. nematophila YL001.
2.5.2. Measurement of Cell Growth. Cell growth was measured by optical density of the culture at $600 \mathrm{~nm}$, and biomass concentrations (dry cell weight: $/ \mathrm{L}$ ) were determined using a calibration curve. The calibration curve was calculated using dilutions of a biomass suspension with known optical density. A fixed volume of the dilutions was centrifuged at 10,000 rpm for $20 \mathrm{~min}$ (Himac CR 22G, Japan). The supernatant was discarded, and the cell pellets were dried at $110^{\circ} \mathrm{C}$ to constant weight. All the cell pellets were weighed after drying. Thus, a relationship between biomass concentration $(\mathrm{g} / \mathrm{L})$ and optical density were determined.

2.5.3. Measurement of Glucose Concentration. The glucose concentration was measured by the 3,5-dinitrosalicylic acid spectrometric method [22].

\section{Results}

3.1. Effects of Initial pH on X. nematophila YL001 Fermentation in Shaking Flasks. Results of the flasks experiments after $72 \mathrm{~h}$ of fermentation with various initial $\mathrm{pH}$ ranging from 4.0 to 10.0 are shown in Figure 1. It is clear that $\mathrm{pH}$ plays an important role in the process of $X$. nematophila YL001 fermentation. Cell concentration and antibiotic activity profiles had a similar trend in response to initial $\mathrm{pH}$. With the increase in initial $\mathrm{pH}$, cell concentration and antibiotic activity increased, and both had a maximum when the initial $\mathrm{pH}$ was 7.0; thereafter, the cell density and antibiotic activity decreased modestly. The maximum DCW and antibiotic activity were $15.68 \mathrm{~g} / \mathrm{L}$ and $80 \mathrm{U} / \mathrm{mL}$, respectively. The influence of $\mathrm{pH}$ on cell growth was not significant as compared to that of antibiotic production within the range of 5.58.5. In spite of the uncontrolled-pH nature of flask cultures, these results indicate that neither the higher $\mathrm{pH}$ nor lower $\mathrm{pH}$ were beneficial to cell growth and antibiotic production. Similar results appeared in the previous work $[16,17]$, in which it was reported that the antibiotic production by $X$. nematophila BJ and Xenorhabdus sp. D43 were affected by the initial $\mathrm{pH}$ within the range of 4.5-8.5 and optimal initial $\mathrm{pH}$ for cell growth and antibiotic production occurred at 6.08.0. However, Wang et al. $[19,21]$ reported that the optimal initial $\mathrm{pH}$ for cell growth and antibiotic production of $X$. nematophila YL001 occurred at 7.64. Nevertheless, with the uncontrolled system, the flask experiment of different initial $\mathrm{pH}$ values might provide the preliminary information of the $\mathrm{pH}$ effects on growth and antibiotic production of $X$. nematophila. The above results showed that it was necessary to investigate the effects of $\mathrm{pH}$ on antibiotic production and cell growth in batch fermentation.

3.2. Kinetics of Batch Fermentation of X. nematophila YL001 at Initial $p H$ 7.0. Based on the results of the flask experiments, the kinetics of batch fermentation of $X$. nematophila YL001 in 5-L laboratory-scale fermenter at initial $\mathrm{pH} 7.0$, agitation speed of $300 \mathrm{rpm}$, aeration ratio of $2.5 \mathrm{~L} / \mathrm{min}$, and fermentation temperature of $28^{\circ} \mathrm{C}$ were studied. Time-course data on DCW, antibiotic activity, glucose concentration, and 


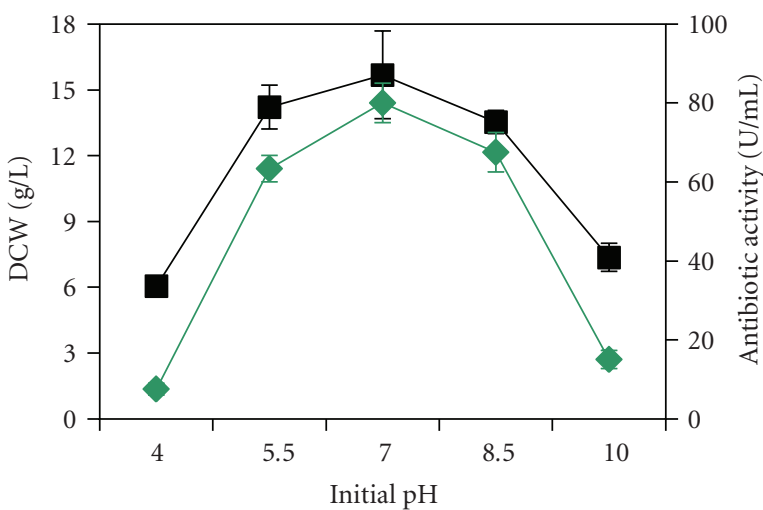

FIgURE 1: Effects of initial pH on dry cell weight (DCW) $(\boldsymbol{\square})$ and antibiotic activity $($ after $72 \mathrm{~h}$ of fermentation with various initial $\mathrm{pH}$ in flask shake cultures.

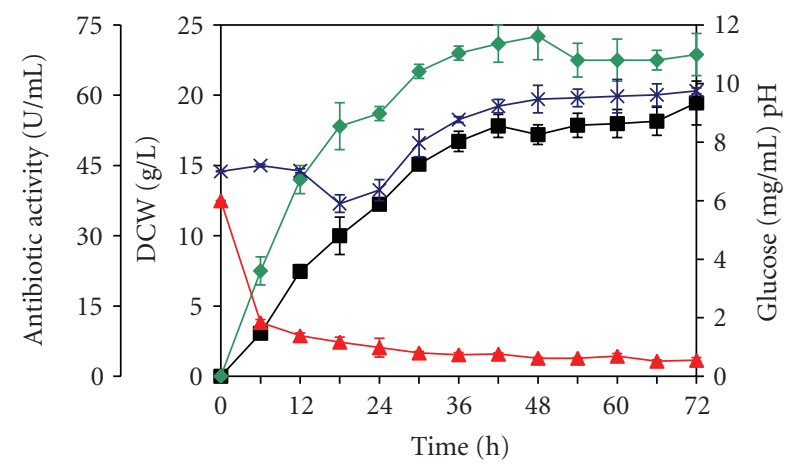

FIgURE 2: Time-course data of batch fermentation in 5-L fermenter with initial $\mathrm{pH}$ at 7.0: dry cell weight $(\mathrm{DCW})(\mathbf{\square})$; antibiotic activity $(\diamond)$; glucose $(\boldsymbol{\Delta})$; and $\mathrm{pH}(\times)$.

$\mathrm{pH}$ are shown in Figure 2. It was found that cell growth showed a distinct exponential phase and a stationary phase; antibiotics biosynthesis occurred throughout the culture and continued even when all the residual sugars were consumed. While culture $\mathrm{pH}$ was uncontrolled, it fell gradually from 7.0 to 5.9 in the early stage of fermentation and then increased gradually to around 9.75 at the end of culture. As with $X$. nematophila YL001 culture, the culture broth $\mathrm{pH}$ of Xenorhabdus sp. RIO decreased during the first few hours of growth and then increased as the bacteria approached and reached stationary phase [23]. This $\mathrm{pH}$ variation may be due to the relatively high glucose consumption at early stage, which might result in production of certain organic acid(s) and would keep the medium $\mathrm{pH}$ at a low value. The $\mathrm{pH}$ increase may be related with ammonia production, a common antibacterial metabolite that is known to be produced by Xenorhabdus sp. in TSB [24]. It seems that to growth and antibiotic activity of $X$. nematophila YL001, it is important to determine the role of $\mathrm{pH}$ at different phase of cell growth and antibiotic production.

3.3. Effect of $p H$ on the Cell Growth of $p H$ Controlled Fermentation. Among the controlled-pH operations, cell formation changed considerably with the $\mathrm{pH}$ operation applied
(Figure 3(c)). The absence of a noticeable lag phase at $\mathrm{pH}$ 6.5 was characterized by a rapid decrease in dissolved oxygen (Figure 4). At $\mathrm{pH} 4.5,7.5$, and 9.5, a lag phase of $18 \mathrm{~h}$ was observed during fermentation. The result may be related to the initial $\mathrm{pH}$; the optimal initial $\mathrm{pH}$ for cell growth was 7.0 (Figure 1). During 0-30 h of the bioprocesses, the DCW was noticeably higher at $\mathrm{pH} 6.5$ than that at all other $\mathrm{pH}$ values assayed, after $42 \mathrm{~h}$, the DCW were higher at $\mathrm{pH} 7.5$ than that at all other $\mathrm{pH}$ values. The maximum DCW of each controlled $\mathrm{pH}$ showed an optimal value of $23.71 \mathrm{~g} / \mathrm{L}$ at $\mathrm{pH}$ 7.5 , and decreased by $45 \%, 12 \%$, and $81 \%$ at $\mathrm{pH} 4.5,6.5$, and 9.5, respectively. The optimal cell yield on glucose $\left(Y_{X / S}\right)$ was $2.50 \mathrm{~g} / \mathrm{g}$ at $\mathrm{pH} 6.5$, which was higher than that at all other $\mathrm{pH}$ values. However, the maximum cell productivity $\left(P_{X}\right)$ occurred at $\mathrm{pH} 7.5$ were $0.33 \mathrm{~g} / \mathrm{L} / \mathrm{h}$. It is obvious that higher or lower culture $\mathrm{pH}$ would inhibit cell formation. Consistent with the decreasing cell growth, the consumption of glucose declined. Especially at $\mathrm{pH} 9.5$, glucose uptake was much slower (Figures 3(a) and 3(b)). These results indicate that shifting of $\mathrm{pH}$ levels greatly affected the cell growth. The optimal pH control strategy for maximal cell growth seemed to be $\mathrm{pH} 6.5$ in the early stage of fermentation and $\mathrm{pH} 7.5$ in the later stage of fermentation.

The specific cell growth rate $(\mu)$ was determined from the slope of the semilogarithmic plot of DCW versus fermentation time. In other words, it was obtained from the following equation:

$$
\mu=\frac{1}{x} \frac{d x}{d t}=\frac{1}{x} \lim _{\Delta t \rightarrow 0} \frac{\Delta x}{\Delta t} .
$$

We interpose normally on the line of cell growth (Figure 3(c)) and compute the DCW at definite time $(\Delta t=0.1 \mathrm{~h}$ ) with GrafTool Version 07.09.97 (LHarc-Archiv), then $\mu$ at definite time was obtained through computing DCW with Microsoft Excel. Time courses of the specific cell growth rate $(\mu)$ at different $\mathrm{pH}$ are shown in Figure 3(d). As shown in Figure 3(d), the $\mu_{\max }$ at different $\mathrm{pH}$ showed that the optimum $\mathrm{pH}$ for cell growth was 6.5 and $\mu_{\max }$ reached $0.092 \mathrm{~h}^{-1}$, but the fastest decreasing rate was observed at this $\mathrm{pH}$ operation. Although $\mu_{\max }$ was correspondingly low at $\mathrm{pH}$ 7.5 compared to that at $\mathrm{pH} 6.5$, the decreasing rate of $\mu$ was small, and $\mu$ reached highest after $16 \mathrm{~h}$. So, it is clear that at the early phase of fermentation, $\mathrm{pH}$ should be controlled at 6.5 in order to shorten the lag phase of cell growth, and thus the total fermentation time, and to maximize the specific cell growth rate.

\subsection{Effect of $p H$ on Antibiotic Activity in $p H$ Controlled Fer- mentation Bioprocess. The effect of controlled $\mathrm{pH}$ on the antibiotic activity of $X$. nematophila YL001 is shown in Figure 3(e). At pH 6.5 and 7.5, the antibiotic activity was higher than that at $\mathrm{pH} 4.5$ and 9.5. During $0-30 \mathrm{~h}$ of the bioprocesses, the antibiotic activity was higher at $\mathrm{pH}$ 6.5 than at $\mathrm{pH}$ 7.5; after $30 \mathrm{~h}$, the antibiotic activity was not significantly different at $\mathrm{pH} 6.5$ and 7.5. The highest antibiotic activity $(100 \mathrm{U} / \mathrm{mL})$ was obtained at $\mathrm{pH} 7.5$, where the highest cell concentration was obtained. On the other hand, at the end of the bioprocesses, the lowest antibiotic}




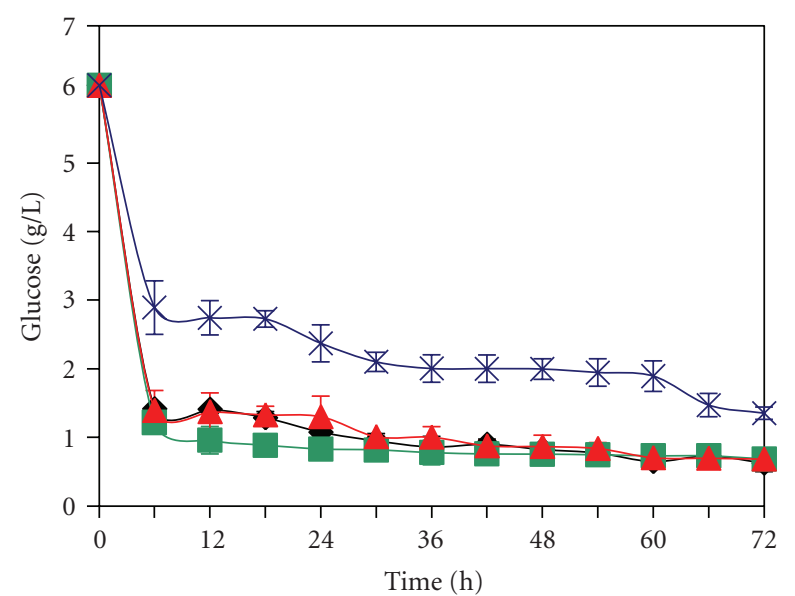

(a)

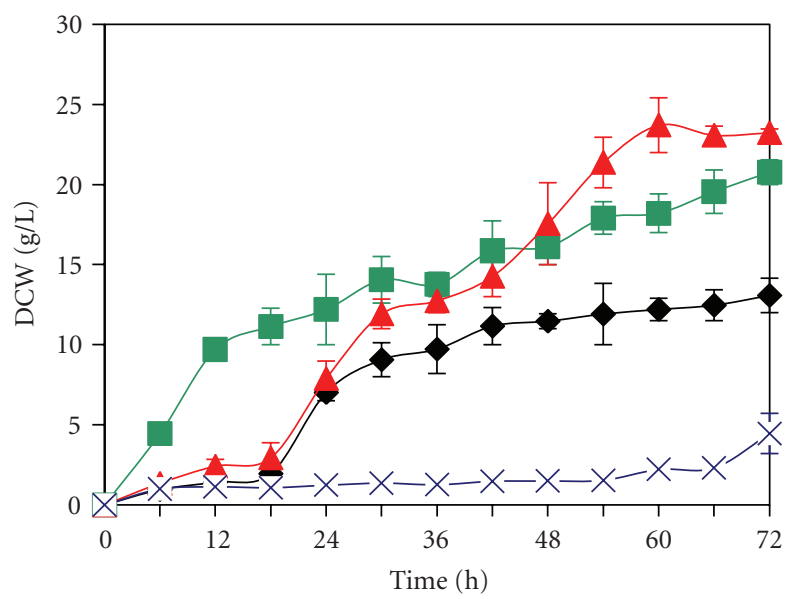

(c)

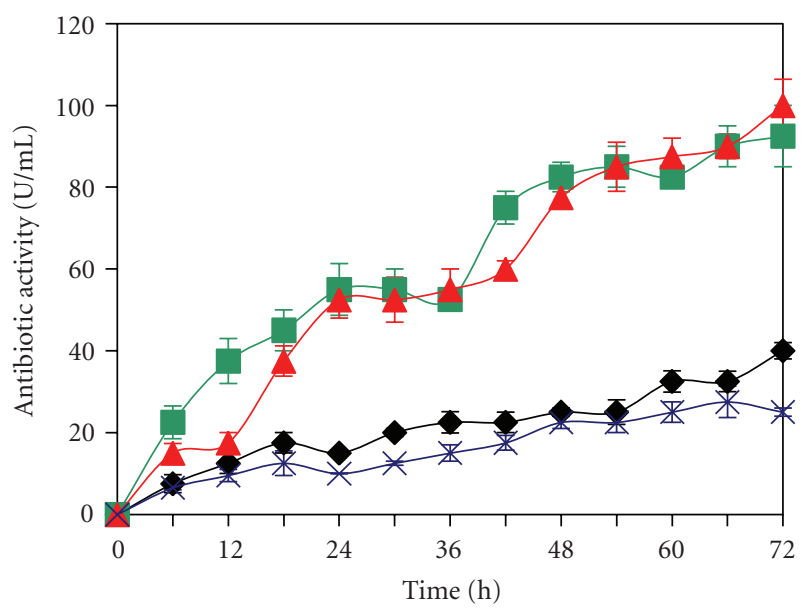

(e)

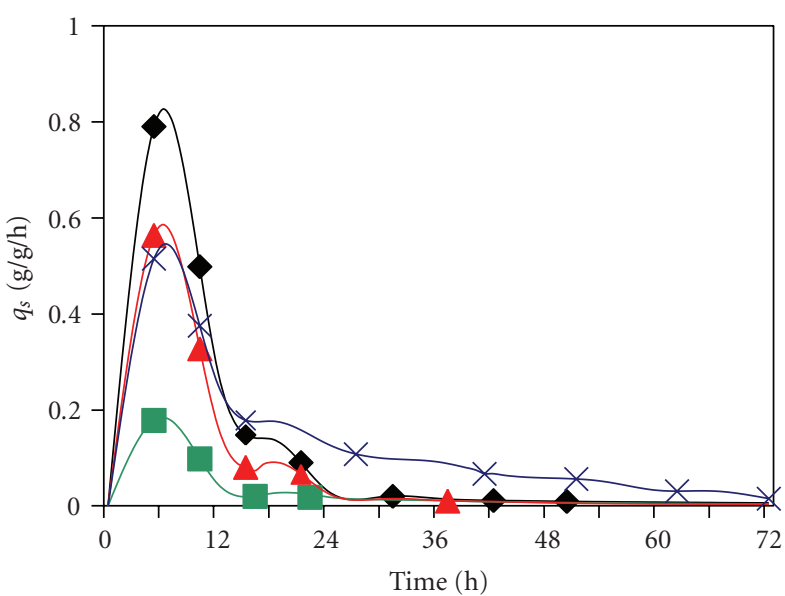

(b)

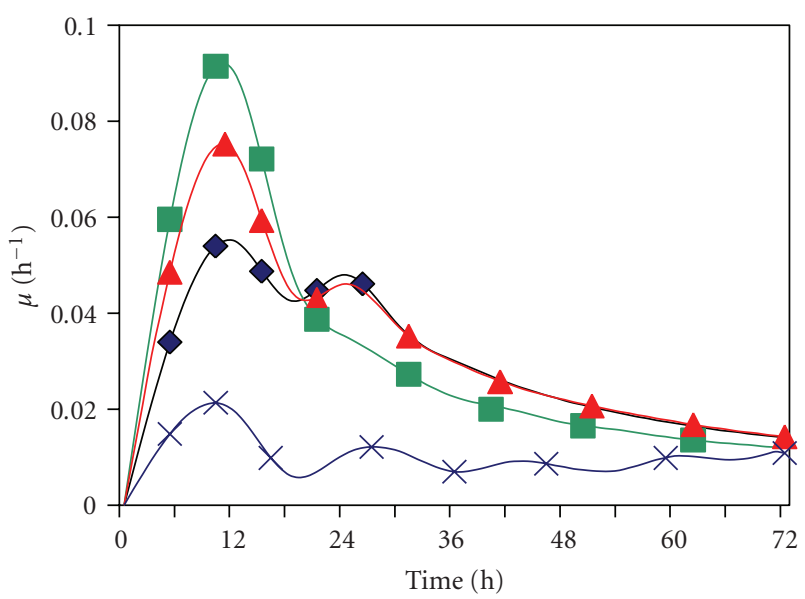

(d)

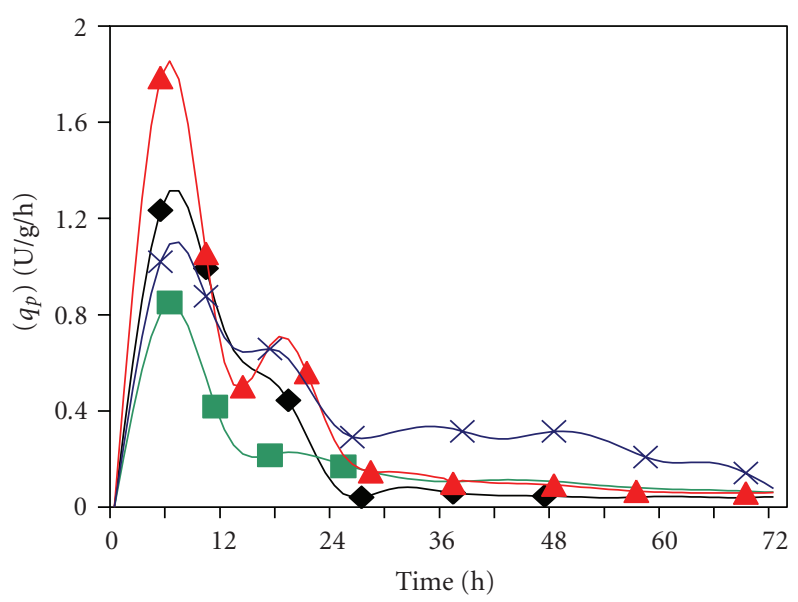

(f)

FIgURE 3: Time profiles of glucose (a), $q_{s}$ specific glucose consumption rates (b), cell growth (c), $\mu$-specific cell growth rate (d), antibiotic activity (e), $q_{p}$-specific antibiotic production rate (f) in the cultivation of X. nematophila YL001 at different $\mathrm{pH} \mathrm{pH} 4.5$ ( ); $\mathrm{pH} 6.5$ ( $\left.\mathbf{\square}\right) ; \mathrm{pH}$ $7.5(\mathbf{\Lambda})$; and $\mathrm{pH} 9.5(\times)$.

activity $(27.5 \mathrm{U} / \mathrm{mL})$ was obtained at $\mathrm{pH} 9.5$, where the least amount of cell was generated. This result in turn indicates that, antibiotic production could be enhanced by increasing the concentration of antibiotic producing cells, probably either by making use of a complex production medium, or developing a substrate feeding strategy, or a combination of both. The maximum antibiotic activity $\left(P_{\max }\right)$ of each $\mathrm{pH}$ controlled showed an optimal value of $100.0 \mathrm{U} / \mathrm{mL}$ at $\mathrm{pH}$ 


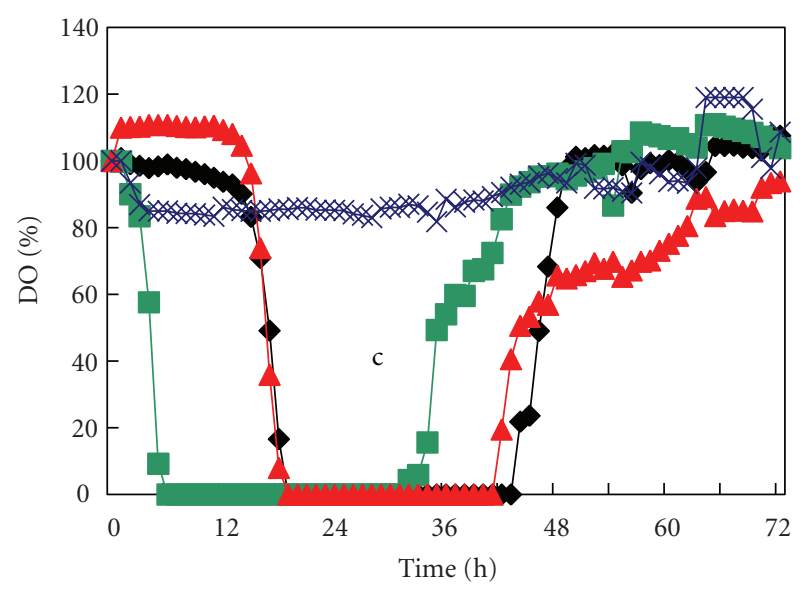

FIgURE 4: The variation in dissolved oxygen concentration with the cultivation time. $\mathrm{pH} 4.5(\checkmark)$; $\mathrm{pH} 6.5(\mathbf{\square})$; $\mathrm{pH} 7.5$ (এ); and $\mathrm{pH}$ $9.5(\times)$.

7.5 , and decreased by $60 \%$ at $\mathrm{pH} 4.5$, decreased by $7.5 \%$ at $\mathrm{pH}$ at 6.5 and decreased by $72.5 \%$ at $\mathrm{pH}$ at 9.5. Likewise, the optimal antibiotic yield on glucose $\left(Y_{P / S}\right)$ and the antibiotic productivity $\left(P_{P}\right)$ occurring at $\mathrm{pH} 7.5$ were $18.36 \mathrm{U} / \mathrm{g}$ and $1.39 \mathrm{U} / \mathrm{mL} / \mathrm{h}$, respectively. However, the optimal antibiotic yield on cell $\left(Y_{P / X}\right)$ was $11.94 \mathrm{U} / g$ obtained at $\mathrm{pH}$ 9.5. It can be concluded that among the controlled-pH operations $\mathrm{pH}$ 7.5 was favorable for antibiotic production due to the higher cell concentration and antibiotic activity obtained.

The specific antibiotic production rate $\left(q_{p}\right)$ was determined from reciprocal of cell density and the slope of antibiotic activity versus fermentation time. In other words, it was obtained from the following equation:

$$
q_{p}=\frac{1}{x} \frac{d p}{d t}=\frac{1}{x} \lim _{\Delta t \rightarrow 0} \frac{\Delta p}{\Delta t}
$$

$q_{p}$ was obtained with the method similar to $\mu$. Profiles of $q_{p}$ at different $\mathrm{pH}$ had similar tendencies, the duration of reaching the maximum $q_{p}$ was similar at different $\mathrm{pH}$, and the decreasing rate was also different after $q_{p}$ reached the maximum (Figure 3(f)). The value of the maximum $q_{p}$ were different at different $\mathrm{pH}$, the highest $q_{p}$ could be achieved at $\mathrm{pH}$ 7.5. During the bioprocesses, at $\mathrm{pH} 6.5$ and 7.5, the average specific antibiotic formation rate was 0.20 and $0.36 \mathrm{U} / \mathrm{g} / \mathrm{h}$, respectively. So, it was concluded that during the whole bioprocess, it is appropriate to control $\mathrm{pH}$ at high value (e.g., $\mathrm{pH} 7.5$ ) to maximize $q_{p}$.

3.5. Two-Stage $p H$-Shift Strategy. During the whole process, the suitable $\mathrm{pH}$ for cell growth and antibiotic formation is different; it is favorable to use a two-stage $\mathrm{pH}$-control process instead of constant $\mathrm{pH}$ process. From the results earlier, relative low $\mathrm{pH}$ value (e.g., $\mathrm{pH}$ 6.5) at earlier fermentation stage not only made the lag phase of cell growth shorter but also was advantageous to cell growth and antibiotic production. At mid- and later-stage, properly increasing $\mathrm{pH}$ value (e.g., $\mathrm{pH}$ 7.5) can strengthen cell growth and antibiotic production (Figures 3(c), 3(d), and 3(e)).

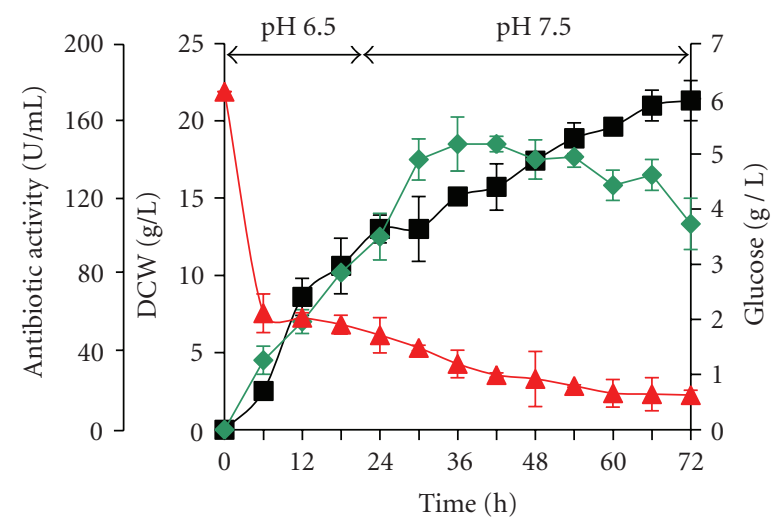

FIGURE 5: Two-stage batch fermentation with $\mathrm{pH}$ shifted from 6.5 to 7.5 after $24 \mathrm{~h}$ fermentation. Dry cell weight (DCW) (ם), glucose $(\boldsymbol{\Lambda})$, and antibiotic activity $(\boldsymbol{})$.

However, Figure 3(f) shown that relative high $\mathrm{pH}$ value (e.g., $\mathrm{pH} 7.5$ ) during the whole bioprocess can increase the antibiotic activity. The approaches to $\mathrm{pH}$ control was not only beneficial to cell growth but also was advantageous to antibiotic production. Based on the above results, a $\mathrm{pH}$-shift culture by combining the first-stage culture at $\mathrm{pH} 6.5$ with the following second-stage culture at $\mathrm{pH} 7.5$ was proposed in order to increase biomass and antibiotic activity. Here, effect of shift time (i.e., hour 12, 24, 36, and 48) between the first stage and the second stage was tested.

The results of fermentation parameters are listed in Table 1. In all cases, a gradual increase of antibiotic activity was observed within the culture time. At the shift time of 12 and $24 \mathrm{~h}$, the antibiotic activity remained unchanged, and was improved significantly compared with that at the shift time of 36 and $48 \mathrm{~h}$. Not only the maximal DCW $\left(X_{\max }\right)$, specific cell growth rate $(\mu)$, cell yield on glucose $\left(Y_{X / S}\right)$ and cell productivity $\left(P_{X}\right)$, but also the maximal antibiotic activity $\left(P_{\max }\right)$, specific antibiotic production rate $\left(q_{p}\right)$, antibiotic yield on glucose $\left(Y_{P / S}\right)$, and antibiotic productivity $\left(P_{P}\right)$ were attained at the shift time of $24 \mathrm{~h}$. Nevertheless, in spite of an increased average specific antibiotic production rate during the whole process, the average specific growth rate remained unchanged at the shift time of 12 and $24 \mathrm{~h}$ (data not shown), suggesting that the additional energy flux obtained from direct fermentation of glucose was used for functions other than growth. The slight increase in $Y_{X / S}$ at the shift time of $24 \mathrm{~h}$ suggests that controlling the $\mathrm{pH}$ would improve the coupling between energy production and biomass synthesis. This indicated that optimal $\mathrm{pH}$-shift controlled strategy was developed as follow: in the first stage, the culture $\mathrm{pH}$ was controlled at a $\mathrm{pH} 6.5$ around $24 \mathrm{~h}$; it was then shifted to $\mathrm{pH} 7.5$ in the secondary stage. The fermentation process in the fermenter with the $\mathrm{pH}$-shift controlled operation was performed to improve the biomass and antibiotic activity as demonstrated in Figure 5.

The antibiotic activity of the two-stage batch fermentation process further enhanced by $46 \%$ and $59 \%$ as compared to that of the fermentation at $\mathrm{pH} 7.5$ and initial $\mathrm{pH} 7.0$, respectively, reaching $185.0 \mathrm{U} / \mathrm{mL}$. The cell yield on glucose 
TABLE 1: The parameters of the batch fermentation of $X$. nematophila YL001 under various $\mathrm{pH}$ controlled processes.

\begin{tabular}{|c|c|c|c|c|c|c|c|c|c|}
\hline $\begin{array}{l}\text { Different } \mathrm{pH} \\
\text { Controlled processes }\end{array}$ & $\begin{array}{l}X_{\max } \\
(\mathrm{g} / \mathrm{L})\end{array}$ & $\begin{array}{c}\mu \\
\left(\mathrm{h}^{-1}\right)\end{array}$ & $\begin{array}{c}P_{X} \\
(\mathrm{~g} / \mathrm{L} / \mathrm{h})\end{array}$ & $\begin{array}{l}Y_{X / S} \\
(g / g) \\
\end{array}$ & $\begin{array}{c}P_{\max } \\
(\mathrm{U} / \mathrm{mL})\end{array}$ & $\begin{array}{c}P_{P} \\
(\mathrm{U} / \mathrm{mL} / \mathrm{h}) \\
\end{array}$ & $\begin{array}{c}q_{p} \\
(\mathrm{U} / \mathrm{g} / \mathrm{h})\end{array}$ & $\begin{array}{c}Y_{P / S} \\
(\mathrm{U} / \mathrm{g})\end{array}$ & $\begin{array}{r}Y_{P / x} \\
(\mathrm{U} / \mathrm{g}) \\
\end{array}$ \\
\hline Initial pH 7.0 (uncontrolled) & 19.45 & 0.10 & 0.27 & 3.49 & 76.0 & 1.58 & 1.086 & 13.80 & 4.42 \\
\hline Controlled at pH 4.5 & 13.07 & 0.055 & 0.18 & 2.37 & 40.0 & 0.56 & 1.316 & 7.23 & 3.06 \\
\hline Controlled at pH 6.5 & 20.77 & 0.092 & 0.29 & 3.82 & 92.5 & 1.29 & 0.844 & 17.00 & 4.45 \\
\hline Controlled at pH 7.5 & 23.71 & 0.075 & 0.33 & 4.37 & 100.0 & 1.39 & 1.855 & 18.36 & 4.30 \\
\hline Controlled at pH 9.5 & 4.46 & 0.021 & 0.06 & 0.93 & 27.5 & 0.42 & 1.093 & 5.90 & 11.94 \\
\hline pH-shift controlled ${ }^{1}$ & 20.57 & 0.074 & 0.29 & 3.51 & 185.0 & 4.41 & 3.317 & 36.13 & 13.10 \\
\hline pH-shift controlled ${ }^{2}$ & 21.31 & 0.079 & 0.30 & 3.87 & 185.0 & 4.41 & 2.986 & 37.65 & 11.77 \\
\hline pH-shift controlled ${ }^{3}$ & 19.53 & 0.060 & 0.27 & 3.55 & 155.0 & 4.31 & 2.402 & 32.43 & 16.40 \\
\hline pH-shift controlled ${ }^{4}$ & 18.46 & 0.072 & 0.26 & 3.37 & 148.3 & 4.12 & 2.385 & 30.58 & 14.13 \\
\hline
\end{tabular}

$X_{\max }$ : maximal dry cell weight; $\mu$ : specific cell growth rate; $P_{X}$ : cell productivity; $Y_{X / S}$ : cell yield on glucose; $P_{\max }$ : maximal antibiotic activity; $P_{P}$ : antibiotic productivity; $q_{p}$ : specific antibiotic production rate; $Y_{P / S}$ : antibiotic yield on glucose; $Y_{P / X}$ : antibiotic yield on cell.

${ }^{1}$ Culture $\mathrm{pH}$ was controlled at $\mathrm{pH} 6.5$ within the first $12 \mathrm{~h}$, then shifted to $\mathrm{pH} 7.5$ until the end of the fermentation.

${ }^{2}$ Culture $\mathrm{pH}$ was controlled at $\mathrm{pH} 6.5$ within the first $24 \mathrm{~h}$, then shifted to $\mathrm{pH} 7.5$ until the end of the fermentation.

${ }^{3}$ Culture $\mathrm{pH}$ was controlled at $\mathrm{pH} 6.5$ within the first $36 \mathrm{~h}$, then shifted to $\mathrm{pH} 7.5$ until the end of the fermentation.

${ }^{4} \mathrm{Culture} \mathrm{pH}$ was controlled at $\mathrm{pH} 6.5$ within the first $48 \mathrm{~h}$, then shifted to $\mathrm{pH} 7.5$ until the end of the fermentation.

of the two-stage process was $3.87 \mathrm{~g} / \mathrm{g}$, which was slightly higher than the $Y_{X / S}, 3.82 \mathrm{~g} / \mathrm{g}$, of the fermentation at $\mathrm{pH}$ 6.5. However, the highest antibiotic yield on cell $\left(Y_{P / X}\right)$ and antibiotic productivity $\left(P_{P}\right)$ of the two-stage fermentation process were achieved at $11.77 \mathrm{U} / \mathrm{g}$ and $4.41 \mathrm{U} / \mathrm{mL} / \mathrm{h}$, respectively. To conclude, a $\mathrm{pH}$-shift culture of $\mathrm{X}$. nematophila YL001 was successfully developed.

\section{Discussion}

Since the phases of a bioprocess are dynamic and are the consequences of directed functioning of the bioreaction network interacting strongly with the microenvironment of the cell, the influence of the operational variable $\mathrm{pH}$ on the overall bioreaction is indeed important and needs clarification in order to develop an operational strategy. In this work, we systematically studied the effect of $\mathrm{pH}$ on growth and activity of X. nematophila YL001. To improve biomass and antibiotic activity, this research used unique strategies. The effects of uncontrolled- (different initial $\mathrm{pH}$ ) and controlled-pH (different constant $\mathrm{pH}$ ) operations on dissolved oxygen, glucose, cell, and antibiotic activity profiles were determined throughout the bioprocess. Based on the kinetic information about $\mathrm{pH}$ effects on the fermentation of $\mathrm{X}$. nematophila YL001, the two-stage $\mathrm{pH}$ control strategy was established to improve the biomass and antibiotic activity.

Under the condition of $\mathrm{pH}$ changing naturally, the maximum biomass and antibiotic activity occurred at initial $\mathrm{pH}$ of 7.0. At initial pH 7.0 with the use of glucose as sole carbon source, the $\mathrm{pH}$ of the fermentation broth varied between 5.9 and 9.75. However, the broth $\mathrm{pH}$ varies with different strains, operational conditions, and medium composition, with the use of complex carbon sources which will result in considerable changes in the medium $\mathrm{pH}$. Isaacson and Webster [23] reported that Xenorhabdus sp. RIO showed growth in vitro similar to that of other Xenorhabdus species grown in TSB, the culture broth $\mathrm{pH}$ of RIO decline from 7.07 to $\mathrm{pH} 6.89$ during the first few hours of growth, and then increased throughout the course of the experiment reaching 8.79 at $168 \mathrm{~h} \mathrm{[23].} \mathrm{The} \mathrm{culture} \mathrm{broth} \mathrm{pH}$ of $\mathrm{X}$. nematophila BJ varied from 6.5 to 8.5 [16]. Although microbial cells have the ability to respond to environment alterations and a remarkable ability to maintain the intracellular $\mathrm{pH}$ at a constant level even with large variations in the $\mathrm{pH}$ of the extracellular medium, the $\mathrm{pH}$ of the environment has a natural tendency to change along with the bioprocess. Provided that these alterations proceed within the acceptable ranges in which growth and metabolism is not effected. In this study, whether the $\mathrm{pH}$ variations go beyond the acceptable ranges and have disadvantageous effect on the growth and antibiotic activity of $X$. nematophila YL001. In order to clarify the problem, the effect of controlled$\mathrm{pH}$ operations on fermentation were determined; the $\mathrm{pH}$ variation values were near the extreme values at initial $\mathrm{pH}$ 7.0, because low and high $\mathrm{pH}$ value (e.g., $\mathrm{pH} 4.5$ and 9.5) was disadvantageous to cell growth and antibiotic production. When $\mathrm{pH}$ was kept stable in the fermentation process, the most optimal reaction condition was at constant $\mathrm{pH}$ of 7.5. However, at earlier fermentation stage, a constant $\mathrm{pH}$ of 6.5 was advantageous to cell growth and antibiotic production, at mid- and later stage, $\mathrm{pH}$ of 7.5 can strengthen cell growth and antibiotic production. Also, in all cases, the antibiotic production could be enhanced by increasing the concentration of antibiotic producing cells. Similar results were obtained in the reports of Sundar and Chang [25], Isaacson and Webster [23] and Ji et al. [4], as the bacterial population increased, the antibacterial activities increased and reached the maximal level at the stationary growth phase of the bacteria $[4,23,25]$. The result also could be validated by the profiles of DO concentration at different constant $\mathrm{pH}$. During $0-18 \mathrm{~h}$, due to higher DCW at $\mathrm{pH} 6.5$ the antibiotic activity was noticeably higher than that at $\mathrm{pH}$ 7.5, this also result in lower DO concentration. After $42 \mathrm{~h}$, the DO concentration was lower at $\mathrm{pH} 7.5$, as the DCW was higher compared to that at $\mathrm{pH}$ 6.5. However, the antibiotic 
activity was not significantly different at $\mathrm{pH} 6.5$ and 7.5 (Figures 3 and 4). In aerobic fermentations, the supply of oxygen is often the rate limiting step and oxygen limitation concomitant with an increase in the cell concentration in culture is well known to have a detrimental effect on cell activity and to decrease the productivity of antibiotics [26]. In this study, DO concentration stabilized at zero level at all constant $\mathrm{pH}$ except for $\mathrm{pH} 9.5$ during the growth phase, and oxygen limitation took place, at mid- and later stage, the DO level increased and a high DO level was maintained throughout the fermentation as the growth of cell was lower. However, at $\mathrm{pH} 9.5$ the DO concentration was above $80 \%$ until the end of fermentation, and the lowest DCW and antibiotic activity was obtained. So, in order to improve the antibiotic activity, the $\mathrm{pH}$ control must be beneficial to the growth of X. nematophila YL001. Based on the results, the two-stage $\mathrm{pH}$ control strategy was developed. The highest antibiotic activity of $185.0 \mathrm{U} / \mathrm{mL}$ was obtained when $\mathrm{pH}$ was shifted from 6.5 to 7.5 on $24 \mathrm{~h}$, which was increased by $50 \%$ and $45.6 \%$ compared with the cultures at $\mathrm{pH} 6.5$ and 7.5 , respectively. By this mechanism, the $\mathrm{pH}$ of the fermentation medium is kept between the desired values without increasing the stress on the microorganism.

Global regulators, which affect the transcription of gene ensembles via regulatory cascades, typically govern the production of small molecules in bacteria [27]. Identification and manipulation of these global regulators could provide a powerful approach to complete sets of biologically important and previously uncharacterized small molecules. Kontnik et al. [28] coupled a global transcriptional regulator, HexA, to secondary metabolite production in Photorhabdus luminescens. P. luminescens $\Delta$ hexA mutant led to dramatic upregulation of biosynthesized small molecules [28]. The CpxRA signal transduction systemis involved in the pathogenic and mutualistic interactions of the entomopathogenic acterium $X$. nematophila [29-31]. The Cpx system of E. coli consists of three proteins, CpxA, CpxR, and CpxP. CpxA, an sensor histidine kinase with autokinase, phosphotransfer, and phospho-CpxR phosphatase activities, is located in the cytoplasmic membrane, where it senses diverse signals, including alkaline $\mathrm{pH}$. In response, CpxA autophosphorylates and donates its phosphoryl group to CpxR, the cognate response regulator. When phosphorylated, this transcription factor controls part of the envelope stress response system, pilus assembly, type III secretion, motility and chemotaxis, adherence, and biofilm development [32]. CpxR negatively influences the antibiotic activities in X.nematophila [29]. So, CpxR-phosphate negatively regulates the antibiotic activities of $X$. nematophila. CpxP was identified as an alkalineinduced member of the Cpx regulon. This periplasmic chaperone binds to the periplasmic domain of CpxA and inhibits its autokinase activity [32]. In this study, when $\mathrm{pH}$ was shifted from 6.5 to 7.5 on $24 \mathrm{~h}$, the alkaline $\mathrm{pH}$ may induced the production of CpxP and inhibits CpxA autophosphorylates and CpxR phosphorylates. So, the antibiotic activities of $X$. nematophila YL001 were enhanced.

\section{Conclusions}

It was demonstrated in this study that different modes of $\mathrm{pH}$ manipulation had remarkably distinct effects on cell growth and antibiotic activity of $X$. nematophila in shaking flasks and 5 - $\mathrm{L}$ fermenter. The optimal initial $\mathrm{pH}$ values for cell growth and antibiotic activity was identified ( $\mathrm{pH}$ 7.0). In the cultivations at constant $\mathrm{pH}$, the highest values of biomass and antibiotic activity were obtained at $\mathrm{pH}$ 7.5. $\mathrm{pH}$ value at a further higher level would inhibit biomass formation and antibiotic activity. Although the lower $\mathrm{pH}$ value (e.g., $\mathrm{pH}$ 6.5) limited cell growth, the biomass and antibiotic activity were relatively higher in the earlier stage of cultivation compared to what gained in the case with a higher $\mathrm{pH}$ value (e.g. $\mathrm{pH}$ 7.5). A two-stage $\mathrm{pH}$ control strategy intending to obtain higher biomass and antibiotic activity throughout the cultivation were proposed. The two-stage $\mathrm{pH}$ control strategy was proved to be the better policy for the enhancement of antibiotic activity and productivity. By fine tuning of $\mathrm{pH}-$ shift strategy, there may be a scope for further enhancement of the antibiotic activity. In addition to $\mathrm{pH}$, other parameters such as dissolved oxygen (including agitation speed and aeration rate) and temperature may also be changed in the two-stage process to optimize cell growth and antibiotic production, respectively. However, this hypothesis remains to be verified further.

\section{Acknowledgment}

The financial support by National Department Public Benefit Research Foundation of China (200903052), Young People Science Program (no. 52211241), and Scientific Research Special Project of Northwest A \& F University is gratefully acknowledged.

\section{References}

[1] G. M. Thomas and G. O. Poinar Jr., "Xenorhabdus gen. nov., a genus of entomopathogenic, nematophilic bacteria of the family Enterobacteriacease," International Journal of Systematic Bacteriology, vol. 29, no. 4, pp. 352-360, 1979.

[2] B. V. McInerney, W. C. Taylor, M. J. Lacey, R. J. Akhurst, and R. P. Gregson, "Biologically active metabolites from Xenorhabdus spp., part 2. Benzopyran-1-one derivatives with gastroprotective activity," Journal of Natural Products, vol. 54, no. 3, pp. 785-795, 1991.

[3] J. Li, G. Chen, and J. M. Webster, "Nematophin, a novel antimicrobial substance produced by Xenorhabdus nematophilus (Enterobactereaceae)," Canadian Journal of Microbiology, vol. 43, no. 8, pp. 770-773, 1997.

[4] D. Ji, Y. Yi, G. H. Kang et al., "Identification of an antibacterial compound, benzylideneacetone, from Xenorhabdus nematophila against major plant-pathogenic bacteria," FEMS Microbiology Letters, vol. 239, no. 2, pp. 241-248, 2004.

[5] G. Lang, T. Kalvelage, A. Peters, J. Wiese, and J. F. Imhoff, "Linear and cyclic peptides from the entomopathogenic bacterium Xenorhabdus nematophilus," Journal of Natural Products, vol. 71, no. 6, pp. 1074-1077, 2008.

[6] J. M. Webster, G. Chen, K. Hu et al., "Bacterial metabolites," in Entomopathogenic Nematology, CAB International Press, Wallingford, UK, 2002. 
[7] Y. H. Wang and X. Zhang, "Isolation and identification of symbiotic bacteria associated with entomopathogenic nematodes," Journal of Northwest A \& F University (Natural Science Edition), vol. 34, pp. 174-180, 2006.

[8] X. L. Fang, Q. Guo, X. H. Yi et al., "Molecule identification and cultivation characteristic of the bacterial symbiont of the entomopathogenic nematode," Journal of Northwest A \& F University (Natural Science Edition), vol. 36, pp. 200-204, 2008.

[9] X. L. Fang, W. G. Zhang, X. H. Yi et al., "Antimicrobial activity of extracellular metabolites of 3 strains the bacterial symbiont of the entomopathogenic nematode," Chinese Journal of Biological Control, vol. 24, pp. 354-358, 2008.

[10] Q. Li, "Preliminary study on activity substances with antibacterial and antifungal effect in fermentation broth of Xenorhabdus nematophila YL001," Yang Ling, Northwest A \& F University, 2006.

[11] J. I. Horiuchi, S. Kikuchi, M. Kobayashi, T. Kanno, and T. Shimizu, "Modeling of $\mathrm{pH}$ response in continuous anaerobic acidogenesis by an artificial neural network," Biochemical Engineering Journal, vol. 9, no. 3, pp. 199-204, 2001.

[12] Z. C. Hu, Y. G. Zheng, Z. Wang, and Y. C. Shen, "pH control strategy in astaxanthin fermentation bioprocess by Xanthophyllomyces dendrorhous," Enzyme and Microbial Technology, vol. 39, no. 4, pp. 586-590, 2006.

[13] L. S. T. Lai, T. H. Tsai, T. C. Wang, and T. Y. Cheng, "The influence of culturing environments on lovastatin production by Aspergillus terreus in submerged cultures," Enzyme and Microbial Technology, vol. 36, no. 5-6, pp. 737-748, 2005.

[14] C. H. Shu and M. Y. Lung, "Effect of $\mathrm{pH}$ on the production and molecular weight distribution of exopolysaccharide by Antrodia camphorata in batch cultures," Process Biochemistry, vol. 39, no. 8, pp. 931-937, 2004.

[15] Y. J. Tang, W. Zhang, and J. J. Zhong, "Performance analyses of a $\mathrm{pH}$-shift and DOT-shift integrated fed-batch fermentation process for the production of ganoderic acid and Ganoderma polysaccharides by medicinal mushroom Ganoderma lucidum," Bioresource Technology, vol. 100, no. 5, pp. 18521859, 2009.

[16] Y. Q. Zhu, W. Y. Tong, D. Z. Wei, F. Zhou, and J. B. Zhao, "Environmental stimuli on the soluble expression of antihuman ovarian carcinoma $\times$ anti-human CD3 single-chain bispecific antibody in recombinant Escherichia coli," Biochemical Engineering Journal, vol. 37, no. 2, pp. 184-191, 2007.

[17] X. F. Yang, H. W. Yang, H. Jian et al., "Effect of fermentation conditions on antibiotic production of Xenorhabdus nematophilus," Chinese Journal of Microbiology, vol. 28, pp. 1216, 2001.

[18] X. F. Yang, D. W. Qiu, N. N. Jiao et al., "Cultural medium and fermentation conditions of Xenorhabdus sp. Strain D43," Chinese Journal of Biological Control, vol. 22, pp. 58-62, 2006.

[19] Y. H. Wang, J. T. Feng, Q. Zhang, and X. Zhang, "Optimization of fermentation condition for antibiotic production by Xenorhabdus nematophila with response surface methodology," Journal of Applied Microbiology, vol. 104, no. 3, pp. 735744, 2008.

[20] P. W. Maxwell, G. Chen, J. M. Webster, and G. B. Dunphy, "Stability and activities of antibiotics produced during infection of the insect Galleria mellonella by two isolates of Xenorhabdus nematophilus," Applied and Environmental Microbiology, vol. 60, no. 2, pp. 715-721, 1994.

[21] Y. H. Wang, Y. P. Li, Q. Zhang, and X. Zhang, "Enhanced antibiotic activity of Xenorhabdus nematophila by medium optimization," Bioresource Technology, vol. 99, no. 6, pp. 1708 $1715,2008$.
[22] G. L. Miller, "Use of dinitrosalicylic acid reagent for determination of reducing sugar," Analytical Chemistry, vol. 31, no. 3, pp. 426-428, 1959.

[23] P. J. Isaacson and J. M. Webster, "Antimicrobial activity of Xenorhabdus sp. RIO (Enterobacteriaceae), symbiont of the entomopathogenic nematode, Steinernema riobrave (Rhabditida: Steinernematidae)," Journal of Invertebrate Pathology, vol. 79, no. 3, pp. 146-153, 2002.

[24] G. Chen, P. Maxwell, G. B. Dunphy et al., "Cultivation conditions for Xenorhabdus and Photorhabdussymbionts of entomopathogenic nematodes," Nematologica, vol. 42, pp. 124127, 1996.

[25] L. Sundar and F. N. Chang, "Antimicrobial activity and biosynthesis of indole antibiotics produced by Xenorhabdus nematophilus," Journal of General Microbiology, vol. 139, no. 12, pp. 3139-3148, 1993.

[26] F. Vardar and M. D. Lilly, "Effect of cycling dissolved oxygen concentrations on product formation in penicillin fermentations," European Journal of Applied Microbiology and Biotechnology, vol. 14, no. 4, pp. 203-211, 1982.

[27] A. Martínez-Antonio and J. Collado-Vides, "Identifying global regulators in transcriptional regulatory networks in bacteria," Current Opinion in Microbiology, vol. 6, no. 5, pp. 482-489, 2003.

[28] R. Kontnik, J. M. Crawford, and J. Clardy, "Exploiting a global regulator for small molecule discovery in Photorhabdusluminescens," ACS Chemical Biology, vol. 5, pp. 659-665, 2010.

[29] E. E. Herbert, K. N. Cowles, and H. Goodrich-Blair, "CpxRA regulates mutualism and pathogenesis in Xenorhabdus nematophila," Applied and Environmental Microbiology, vol. 73, no. 24, pp. 7826-7836, 2007.

[30] E. E. Herbert Tran and H. Goodrich-Blair, "CpxRA contributes to Xenorhabdus nematophila virulence through regulation of lrhA and modulation of insect immunity," Applied and Environmental Microbiology, vol. 75, no. 12, pp. 39984006, 2009.

[31] E. E. Herbert Tran, A. W. Andersen, and H. GoodrichBlair, "CpxRA influences Xenorhabdus nematophila colonization initiation and outgrowth in Steinernema carpocapsae nematodes through regulation of the nil locus," Applied and Environmental Microbiology, vol. 75, pp. 4007-4014, 2009.

[32] A. J. Wolfe, N. Parikh, B. P. Lima, and B. Zemaitaitis, "Signal integration by the two-component signal transduction response regulator CpxR," Journal of Bacteriology, vol. 190, no. 12, pp. 2314-2322, 2008. 

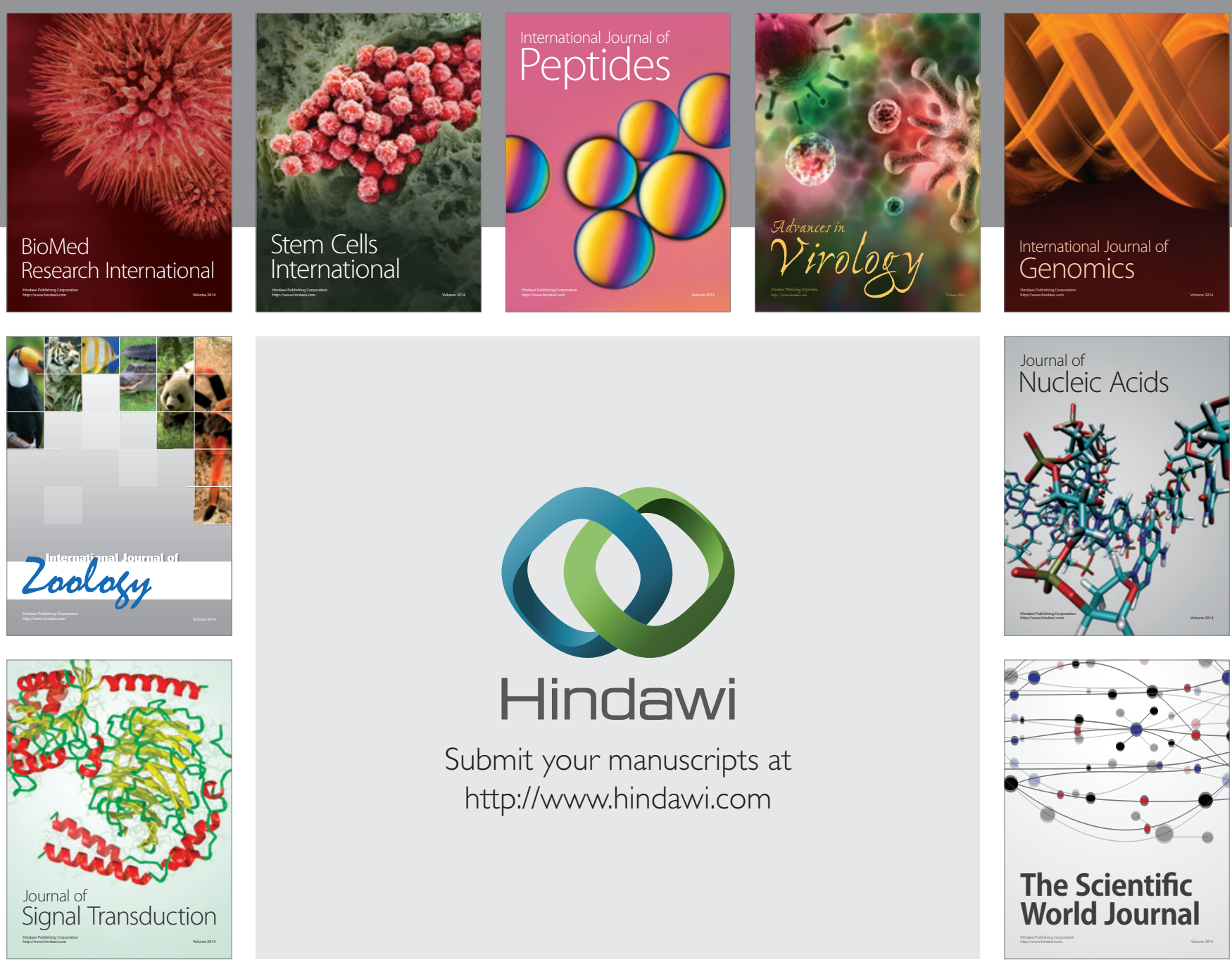

Submit your manuscripts at

http://www.hindawi.com
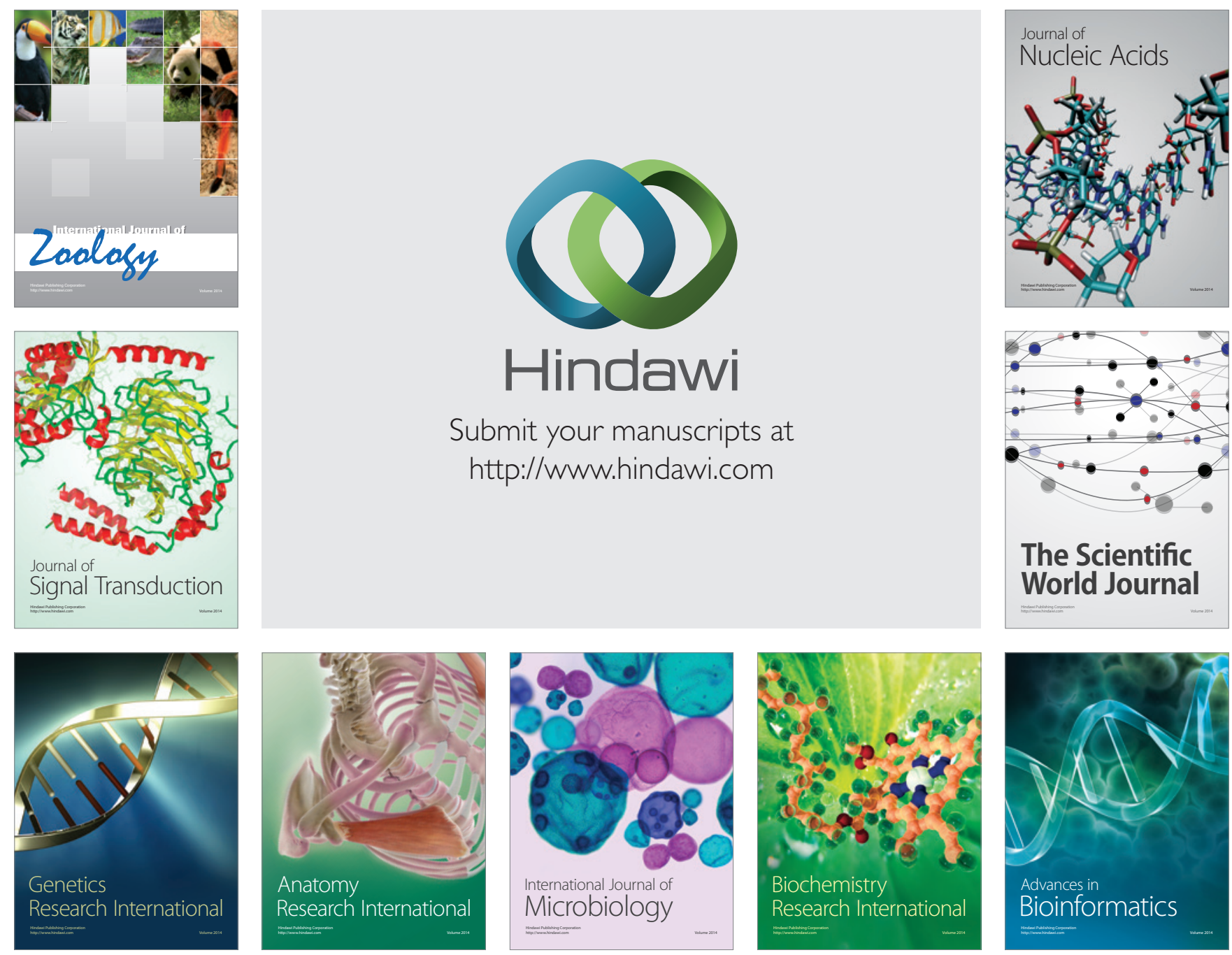

The Scientific World Journal
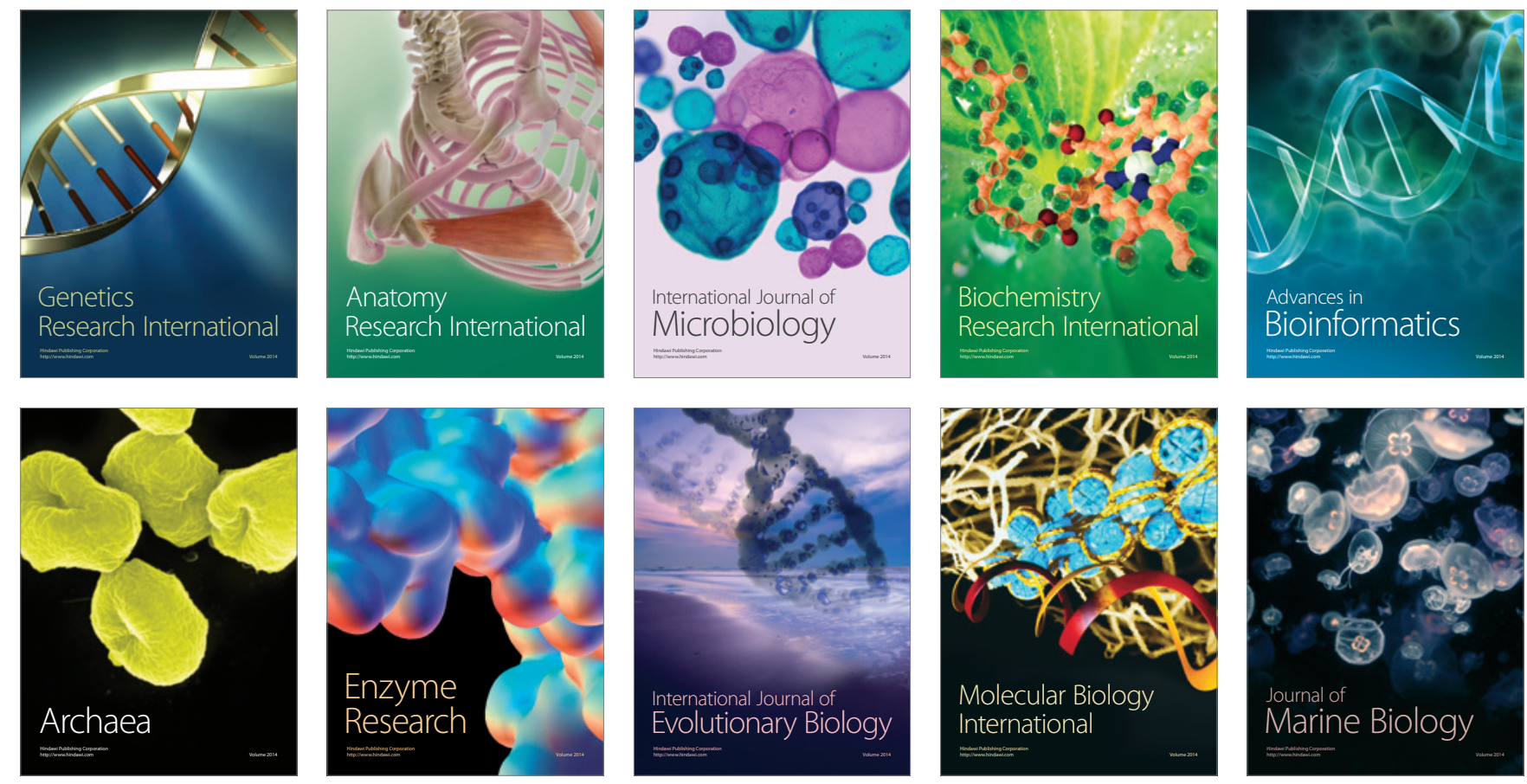